\title{
Alteration of MMP-2 and -14 expression by imatinib in HPV-positive and -negative squamous cell carcinoma
}

\author{
ANNE FABER $^{1}$, ALEXANDER SAUTER ${ }^{1}$, SARAH HOEDT $^{1}$, KARL HOERMANN $^{1}$, \\ PHILIPP ERBEN $^{2}$, RALF-DIETER HOFHEINZ ${ }^{2}$, ULRICH SOMMER ${ }^{1}$, \\ JENS STERN-STRAETER ${ }^{1}$ and DAVID JOHANNES SCHULTZ ${ }^{1}$ \\ Departments of ${ }^{1}$ Otorhinolaryngology Head and Neck Surgery, ${ }^{2}$ Hematology and Oncology, \\ University Medical Centre Mannheim, D-68167 Mannheim, Germany
}

Received December 31, 2011; Accepted February 9, 2012

DOI: 10.3892/or.2012.1766

\begin{abstract}
Head and neck squamous cell carcinoma (HNSCC) is an aggressive epithelial malignancy. It is known to be the most common neoplasm appearing in the upper aerodigestive tract. The poor 5-year survival rate has remained unchanged in the last decades even though improved techniques in surgery, radiation and chemotherapy have been established. In contrast to the overall decreasing incidence of head and neck cancer in the US, the incidence of HPV-associated oropharyngeal cancer is increasing, indicating the importance of viral etiology. Furthermore, growth and invasion of HNSCC are strongly influenced by the extracellular matrix (ECM). Matrix metalloproteinases (MMP) have been shown to play key roles in the remodeling of the ECM. Imatinib (STI 571) was originally designed to inhibit the BCR-ABL tyrosine kinase in chronic myeloid leukaemia. But it also has an inhibitory impact, e.g., on the protein-tyrosine-kinase (PTK) receptor c-kit and on its PTK activity in HNSCC. In this study, we incubated the HNSCC cell lines HNSCC 11 A and 14C and the p16-positive SCC line CERV196 with increasing concentrations of imatinib or carboplatin. After an incubation time of up to 10 days, we evaluated MMP-2 and -14 expression by ELISA techniques and immunohistochemistry. MMP-2 and -14 expression was demonstrated in all incubated tumor cell lines. Especially incubation with imatinib resulted in a significant decrease in MMP expression in incubated cell lines. Our results indicate that the expression of MMP-2 and -14 is suppressed in the presence of imatinib. Thus, imatinib may exert in part its inhibitory effect on malignant cell growth via the blockage of the signal transduction of PTK receptors. Further studies are
\end{abstract}

Correspondence to: Dr Anne Faber, Department of Otorhinolaryngology Head and Neck Surgery, University Medical Centre Mannheim, Theodor-Kutzer-Ufer 1-3, D-68167 Mannheim, Germany E-mail: faberanne@gmx.de; anne.faber@umm.de

Key words: imatinib, MMP-2, MMP-14, head and neck squamous cell carcinoma, head and neck squamous cell carcinoma, proteintyrosine-kinase, human papilloma virus warranted, especially keeping in mind the moderate toxicity of imatinib.

\section{Introduction}

Head and neck squamous cell carcinoma. Head and neck squamous cell carcinoma (HNSCC) is an aggressive epithelial malignancy. It is the most common neoplasm arising in the upper aerodigestive tract. According to actual data, HNSCC is the sixth of the most common cancers in the world (1). Unfortunately, the survival rate for this type of cancer has not improved significantly in the past 25 years (2). The overall 5 -year relative survival rate for HNSCC is less than 50\% (3). The management of the malignancy requires multimodal therapy including surgery, chemoradiation or a combination of these strategies (2). Chemotherapy is employed in the majority of advanced cases, but the response rates are poor (3). Thus, new treatment modalities are developed to improve long-term survival in HNSCC disease. In the past few years, many biological markers have been described in HNSCC. For example, various studies have suggested potential prognostic values for p53 mutations, enhanced expression of epidermal growth factor (EGFR), transforming growth factor- $\alpha$ (TGF- $\alpha$ ) or cyclin D1 (4-6). More recently, novel CD44v6 targeting humanized antibodies were coupled with toxic substances in order to improve response rates in $\operatorname{HNSCC}(7,8)$.

Human papilloma virus. In the past 20 years increasing evidence has accumulated, that there is a subset of squamous cell carcinoma, that is induced by oncogenic forms of the human papilloma virus (HPV). High-risk HPV infection has been shown to be associated with anogenital carcinomas including cervical, anal, vulvar and penile cancers $(9,10)$ and more recently, breast cancer (11). In contrast to the decreasing incidence of head and neck cancers overall in the US in recent years, the incidence of HPV-associated oropharyngeal cancer is rising, indicating the increasing importance of viral etiology (12). In the US, $40-80 \%$ of oropharyngeal cancers are associated with HPV. In Europe data are heterogeneous and vary from $20 \%$ in countries with high consumption of tobacco and alcohol to $90 \%$ in Sweden. This suggests that HPV is now the primary cause of tonsillar carcinoma in North America and 
Europe (13-17). The International Agency for Research on Cancer (IARC) designated HPV as a risk factor for cancerogenesis of oropharyngeal cancer and recent molecular and epidemiological data support this theory $(18,19)$. HPV-positive HNSCC occur more often in younger patients with minimal tobacco exposure but more exposure to marijuana, oral sex or multiple sexual partners (20). This is consistent with the known predominant means of HPV transmission via sexual contact (21). HPV-positive HNSCC patients are often of higher socioeconomic status with better dentition, nutritional status and overall health compared to HPV-negative patients (13). HPV is a circular, double-stranded DNA-virus. The viral genome, consisting of approximately 8000 base pairs, encodes two regulatory proteins, three oncoproteins (E5, E6 and E7) and two structural capsid proteins (L1 and L2) (14). At present, the family of Papillomavididae contains at least 200 genotypes or subtypes based on the ability to infect mucosal surfaces and based on genomic characteristics (22). These subtypes can be classified in low- and high-risk subpopulations based on their capacity to persist in basal mucosal cells, thereby avoiding the clearance of the immune system and by expression of viral oncogenes. Mucosal HPV infections are known to be associated with a spectrum of human diseases, ranging from benign papillomas to invasive carcinomas such as cervical, vulvar, vaginal, anal, penile and more recently HNSCC (13).

Protein tyrosine kinases. An essential element of signal transduction pathways are protein tyrosine kinases (PTK). The intracellular signal transduction is of essential interest in cell growth, metastasis and apoptosis. Numerous factors regulate the activities of these PTKs. However, genetic alterations of PTKs often cause malignant transformations (23). Especially transmembrane PTK receptors are of interest. These receptors are responsible for the transduction of signals from outside and inside the cell. PTKs are impotant targets for chemical agents that inhibit their activity. In HNSCC mainly the EGFR-PTK inhibitor gefitinib (Iressa ${ }^{\circledR}$ ) has been studied extensively (24).

Imatinib. The PTK inhibitor imatinib (Glivec ${ }^{\circledR}$ or Gleevec ${ }^{\circledR}$, also known as STI 571, Novartis, Basel, Switzerland) belongs to the 2-phenylaminopyrimidine class, which was developed for its selectivity against BCR-ABL in patients with chronic myeloid leukemia (CML) (25), but it is also an inhibitor of platelet-derived growth factor receptor $(\operatorname{PDGFR}) \operatorname{PTK}(26,27)$. Recently, the crucial role of PDGFR in HNSCC growth has been described (28). The inhibitory effects of imatinib occur by binding with non-reserved amino-acid residues in the ATP-binding site of mutant PTKs (26). In consequence the auto-phosphorylation is being blocked and an alteration of the PTK is taking place.

Matrix metalloproteinases. Matrix metalloproteinases (MMP) represent a family of zinc- or calcium-dependent endopeptidases. MMPs degrade as gelatinases the extracellular matrix (ECM). This degradation of the ECM plays a key role in tumor angiogenesis, progression and facilitates metastasis. Expression of MMP-2 is associated with tumor invasion and metastasis in HNSCC (29). Okada et al reported that the majority of MMPs are generated in the stromal compartment by fibroblast tissue surrounding the tumor (30). Most MMPs are destined for secretion into the extracellular milieu. In contrast to this, MMP-14 is a membrane type-MMP (31). It is a critical protein in cancer invasion and metastasis. Invasion through collagen networks and subsequent collagenolysis relies principally on MMP-14, not on secreted MMPs (32). The purpose of this study was to evaluate the effects of the chemotherapeutic agents carboplatin and imatinib (STI 571) in HNSCC culture.

\section{Materials and methods}

Cell lines and cell culture. The two HNSCC cell lines 11A and 14C (UMSCC 11A/14C) were obtained from Dr T.E. Carey (University of Michigan, MI, USA). They originate from human HNSCC of larynx (11A) and of the oral cavity (14C). The p16 positive cell line CERV196 was provided by the CLS (Eppelheim, Germany).

Cell cultures were carried out at $37^{\circ} \mathrm{C}$ in a $5 \% \mathrm{CO}_{2}$ fully humidified atmosphere using Dulbecco's modified minimum essential medium (DMEM) (Fisher Scientific Co., Pittsburgh, PA, USA) supplemented with $10 \%$ fetal calf serum (FCS) and antibiotics (Life Technologies Inc., Gainthersburg, MD, USA). Imatinib was provided by the manufacturer (Novartis). Imatinib and carboplatin (Medac, Wedel, Germany) were stored at $4^{\circ} \mathrm{C}$ and dissolved in sterile water at the time of use. HNSCC cell lines $11 \mathrm{~A} / 14 \mathrm{C}$ and the papilloma virus positive cervical cancer cell line CERV196 were incubated with different concentrations of imatinib (18 or $30 \mu \mathrm{mol} / \mathrm{ml}$ ) or carboplatin ( 3 or $7.5 \mu \mathrm{mol} / \mathrm{ml}$ ) from $48 \mathrm{~h}$ to 10 days. After the defined incubation time the supernatants were collected in sterile tubes and stored at $-20^{\circ} \mathrm{C}$ until further analysis.

MMP-ELISA principle. MMP-2 and MMP-14 concentrations were determined by ELISA technique (DMP2F0. R\&D Systems, Wiesbaden, Germany). The system used a solidphase monoclonal antibody and further an enzyme-linked polyclonal antibody against MMP-2/-14. The specificity of anti-human antibodies used in the ELISA kit were examined by sodium dodecylsulphate polyacrylamide gel electrophoresis (SDS-PAGE) followed by further western blotting. Following the manufacturer's instructions, each assay measured $100 \mu \mathrm{l}$ of supernatant. All calibrations and analyses were carried out in duplicate. Optical density was determined using a microplate reader at a wavelength of $450 \mathrm{~nm}$. Wavelength correction was set to $540 \mathrm{~nm}$. Concentrations of MMP-2 and -14 were reported as ng/ml. After 48 and 72 h, 5, 8 and 10 days of incubation with 3 or $7.5 \mu \mathrm{mol}$ carboplatin, 18 or $30 \mu \mathrm{mol}$ imatinib the expression of MMP-2 and MMP-14 in the supernatants of the incubated cultures and untreated cultures was determined.

Characterisation of cell lines (immunohistochemistry). Immunohistochemical studies were performed using a monoclonal mouse anti-human antibody directed against MMP-2/-14 (ab7032/73879, Abcam, Cambridge, UK). Immunostaining was performed using the streptavidin horseradish method. The cells were cultured on Nunc 8-well chambers overnight before immunohistochemistry. When confluent, cells underwent fixation with acetone and alcohol (2:1). Cells were incubated with primary antibody solution for $30 \mathrm{~min}$ at room temperature, using a working solution of antibody to cells of 1:300. Slides 
were rinsed three times in buffer (Buffer Kit, Dako, Hamburg, Germany). Furthermore, cells were incubated in sheep serum. Immunoreaction was demonstrated with the monoclonal mouse anti-human antibody MMP-2/-14 (ab7032/ab73879, Abcam). Incubtion was followed by addition of a specific biotinylated secondary antibody and a streptavidin-biotin horseradish peroxidase complex (Amersham, Freiburg, Germany), then peroxidase reaction was performed using aminoethylcarbazol as chromogen. After blocking of endogenous peroxidase, cells were washed several times. Finally sections received a counterstaining with Harris' hematoxylin for $30 \mathrm{sec}$. This procedure was followed by coverslipping. Negative controls were used with the reagents except the primary antibody. The results of the immunohistochemically observed rates of expression were determined semi-quantitatively. The staining intensity was: strong reactivity, $>80 \%$ of the cells were positive; moderate reactivity, $50-80 \%$ of the cells stained positive; weak reactivity, $<50 \%$ of the cells were positive, and no positive cells.

Statistical analysis. Statistical analysis was performed in cooperation with Dr C. Weiss, Institute of Biomathematics, Faculty of Medicine, Mannheim. The differences in MMP expression between incubated cultures and control cultures were analyzed using the Dunnet's test being part of GLM procedure. All treated groups were measured as mean $(\diamond$ in Figs. 1-5) and compared to the negative control. A P-value $\leq 0.05$ was considered statistically significant. In Figs. 1-5 significant data are marked as follows: ${ }^{*} \mathrm{P}<0.05 ;{ }^{* *} \mathrm{P}<0.005$; ${ }^{* * *} \mathrm{P} \leq 0.001 ;{ }^{* * * *} \mathrm{P} \leq 0.0006$.

\section{Results}

Effect of carboplatin and imatinib on SCC cell lines. To analyze the effects of imatinib and carboplatin on HNSCC cell lines and the HPV-positive cell line CERV196, we added increasing concentrations of the two chemotherapeutical agents imatinib (18 and $30 \mu \mathrm{mol}$ ) and carboplatin ( 3 and $7.5 \mu \mathrm{mol})$ to cell cultures. In order to determine MMP-2 as well as MMP-14 expression in the supernatant of the cell lines, ELISA analysis was carried out at 2, 3, 5, 8 and 10 days after the start of incubation.

In all cell lines treated a downregulation of MMP-2 was shown by incubation with imatinib. A significant effect could be measured after 2 days in HNSCC $11 \mathrm{~A}$ cell line and on day 3 in HNSCC 14C and CERV196. All treated groups were measured as mean and compared to the negative control after 3 days of incubation with imatinib (e.g., $18 \mu \mathrm{mol} /$ $\mathrm{ml}$ ): cont $_{11 \mathrm{~A}}=0.663 \pm 0.086 \mathrm{ng} / \mathrm{ml}, \mathrm{m}_{11 \mathrm{~A}}=0.378 \pm 0.10 \mathrm{ng} / \mathrm{ml}$, $\mathrm{P}_{11 \mathrm{~A}}=0.018 ;$ cont $_{14 \mathrm{C}}=0.746 \pm 0.069 \mathrm{ng} / \mathrm{ml}, \mathrm{m}_{14 \mathrm{C}}=0.415 \pm 0.126 \mathrm{ng} /$ $\mathrm{ml}, \mathrm{P}_{14 \mathrm{C}}=0.003$; cont $_{\mathrm{CERV} 196}=0.412 \pm 0.018 \mathrm{ng} / \mathrm{ml}, \mathrm{m}_{\mathrm{CERV} 196}=$ $0.224 \pm 0.032 \mathrm{ng} / \mathrm{ml}, \mathrm{P}_{\mathrm{CERV} 196}=0.007$. A significant downregulation of MMP-2 could not be shown by treatment of cell lines with carboplatin (Fig. 1).

In HNSCC $11 \mathrm{~A}$ a time-dependence of MMP-2 downregulation by imatinib was revealed (e.g., $30 \mu \mathrm{mol}$ ): cont $_{0 \mathrm{~d}}=0.516 \pm 0.098 \mathrm{ng} / \mathrm{ml} ;$ cont $_{2 \mathrm{~d}}=0.601 \pm 0.109 \mathrm{ng} / \mathrm{ml}$; $\mathrm{m}_{2 \mathrm{~d}}=0.344 \pm 0.118 \mathrm{ng} / \mathrm{ml}, \mathrm{P}_{2 \mathrm{~d}}=0.004 ;$ cont $_{3 \mathrm{~d}}=0.663 \pm 0.086 \mathrm{ng} / \mathrm{ml}$, $\mathrm{m}_{3 \mathrm{~d}}=0.385 \pm 0.077 \mathrm{ng} / \mathrm{ml}, \mathrm{P}_{3 \mathrm{~d}}=0.018 ;$ cont $_{5 \mathrm{~d}}=0.727 \pm 0.15 \mathrm{ng} / \mathrm{ml}$, $\mathrm{m}_{5 \mathrm{~d}}=0.408 \pm 0.09 \mathrm{ng} / \mathrm{ml}, \mathrm{P}_{5 \mathrm{~d}}=0.015 ;$ cont $_{8 \mathrm{~d}}=0.956 \pm 0.125 \mathrm{ng} / \mathrm{ml}$, $\mathrm{m}_{8 \mathrm{~d}}=0.369 \pm 0.062 \mathrm{ng} / \mathrm{ml}, \mathrm{P}_{8 \mathrm{~d}}=0.001 ;$ cont $_{10 \mathrm{~d}}=0.794 \pm 0.105 \mathrm{ng} / \mathrm{ml}$,

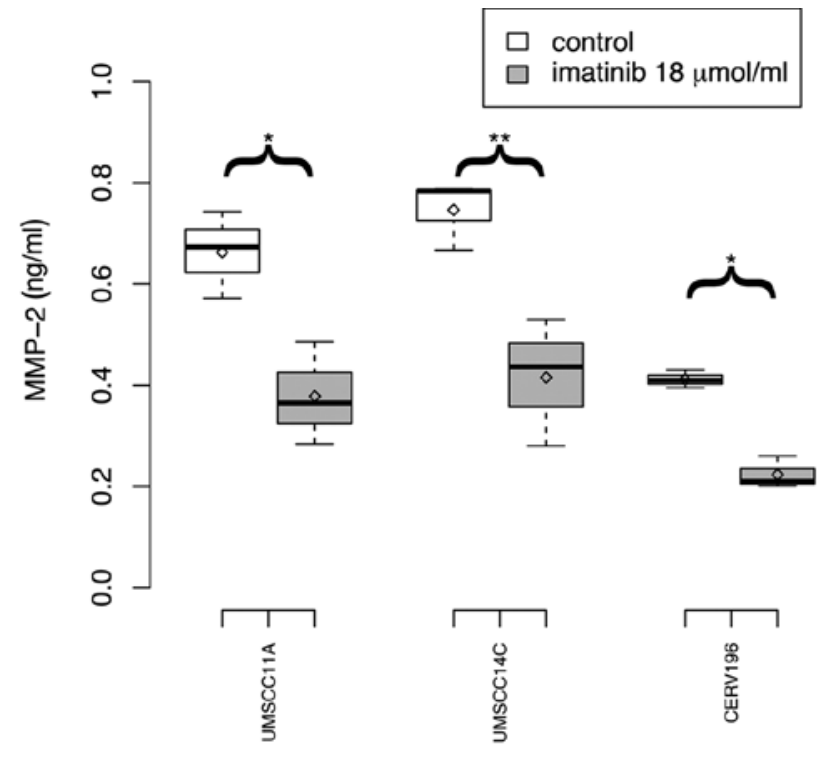

Figure 1. Downregulation of MMP-2 by incubation with imatinib in SSC cell lines. A significant effect was measured after 2 days in HNSCC 11A cell line and on day 3 in HNSCC 14C and CERV196. All treated groups were measured as mean $(\diamond)$ and compared to the negative control after 3 days of incubation with imatinib (e.g., $18 \mu \mathrm{mol} / \mathrm{ml}$ ): cont $_{11 \mathrm{~A}}=0.663 \pm 0.086 \mathrm{ng} / \mathrm{ml}$, $\mathrm{m}_{11 \mathrm{~A}}=0.378 \pm 0.101 \mathrm{ng} / \mathrm{ml}, \mathrm{P}_{11 \mathrm{~A}}=0.018\left({ }^{*} \mathrm{P}<0.05\right) ;$ cont $_{14 \mathrm{C}}=0.746 \pm 0.069 \mathrm{ng} / \mathrm{ml}$, $\mathrm{m}_{14 \mathrm{C}}=0.415 \pm 0.126 \mathrm{ng} / \mathrm{ml}, \mathrm{P}_{14 \mathrm{C}}=0.003\left({ }^{* *} \mathrm{P}<0.005\right) ;$ cont $_{\mathrm{CERV} 196}=0.412 \pm 0.018 \mathrm{ng} /$ $\mathrm{ml}, \mathrm{m}_{\text {CERV } 196}=0.224 \pm 0.032 \mathrm{ng} / \mathrm{ml}, \mathrm{P}_{\text {CERV } 196}=0.007\left({ }^{*} \mathrm{P}<0.05\right)$. A significant downregulation of MMP-2 could not be shown by treatment of cell lines with carboplatin.

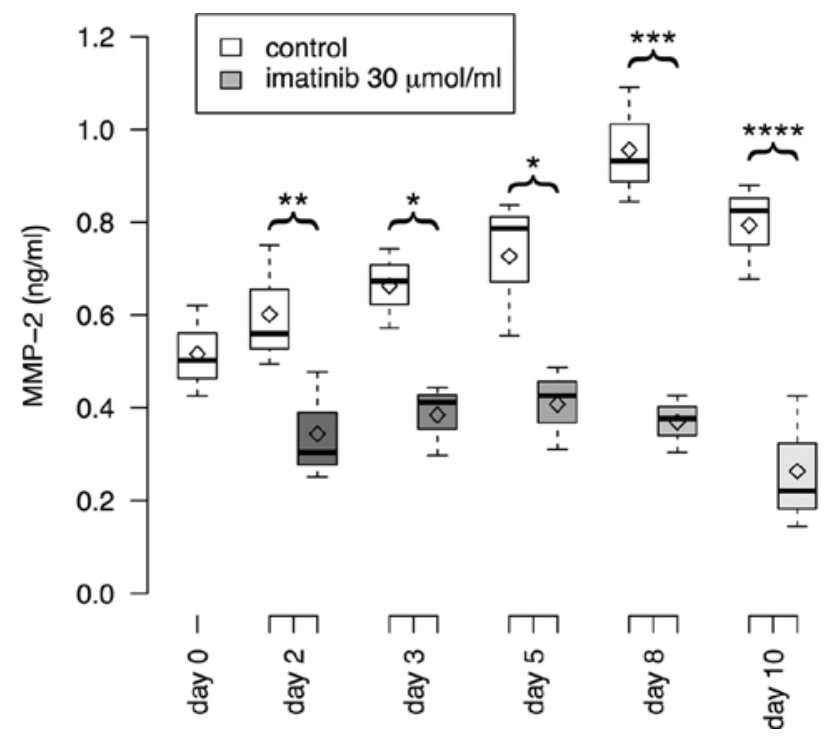

Figure 2. Time-dependence of MMP-2 downregulation by imatinib in HNSCC 11A. In HNSCC 11A MMP-2 was downregulated by incubation with imatinib in a time-dependent manner (e.g., $30 \mu \mathrm{mol}$ ): cont $_{0 \mathrm{~d}}=0.516 \pm 0.098 \mathrm{ng} /$ $\mathrm{ml}$, cont $_{2 \mathrm{~d}}=0.601 \pm 0.109 \mathrm{ng} / \mathrm{ml}, \mathrm{m}_{2 \mathrm{~d}}=0.344 \pm 0.118 \mathrm{ng} / \mathrm{ml}, \mathrm{P}_{2 \mathrm{~d}}=0.004$ $(* * \mathrm{P}<0.005) ;$ cont $_{3 \mathrm{~d}}=0.663 \pm 0.086 \mathrm{ng} / \mathrm{ml}, \mathrm{m}_{3 \mathrm{~d}}=0.385 \pm 0.077 \mathrm{ng} / \mathrm{ml}, \mathrm{P}_{3 \mathrm{~d}}=0.018$ ( $\left.{ }^{*} \mathrm{P}<0.05\right) ;$ cont $_{5 \mathrm{~d}}=0.727 \pm 0.15 \mathrm{ng} / \mathrm{ml}, \mathrm{m}_{5 \mathrm{~d}}=0.408 \pm 0.09 \mathrm{ng} / \mathrm{ml}, \mathrm{P}_{5 \mathrm{~d}}=0.015$ $\left({ }^{*} \mathrm{P}<0.05\right) ;$ cont $_{8 \mathrm{~d}}=0.956 \pm 0.125 \mathrm{ng} / \mathrm{ml}, \mathrm{m}_{8 \mathrm{~d}}=0.369 \pm 0.062 \mathrm{ng} / \mathrm{ml}, \mathrm{P}_{8 \mathrm{~d}}=0.001$ $\left({ }^{* * *} \mathrm{P} \leq 0.001\right) ;$ cont $_{10 \mathrm{~d}}=0.794 \pm 0.105 \mathrm{ng} / \mathrm{ml}, \mathrm{m}_{10 \mathrm{~d}}=0.264 \pm 0.146 \mathrm{ng} / \mathrm{ml}, \mathrm{P}_{10 \mathrm{~d}}=0.0006$ $\left({ }^{* * * *} \mathrm{P} \leq 0.0006\right)$.

$\mathrm{m}_{10 \mathrm{~d}}=0.264 \pm 0.146 \mathrm{ng} / \mathrm{ml}, \mathrm{P}_{10 \mathrm{~d}}=0.0006$ (Fig. 2). Concentration of imatinib did not influence the effect of MMP-2 supression significantly in any of the cell lines. 


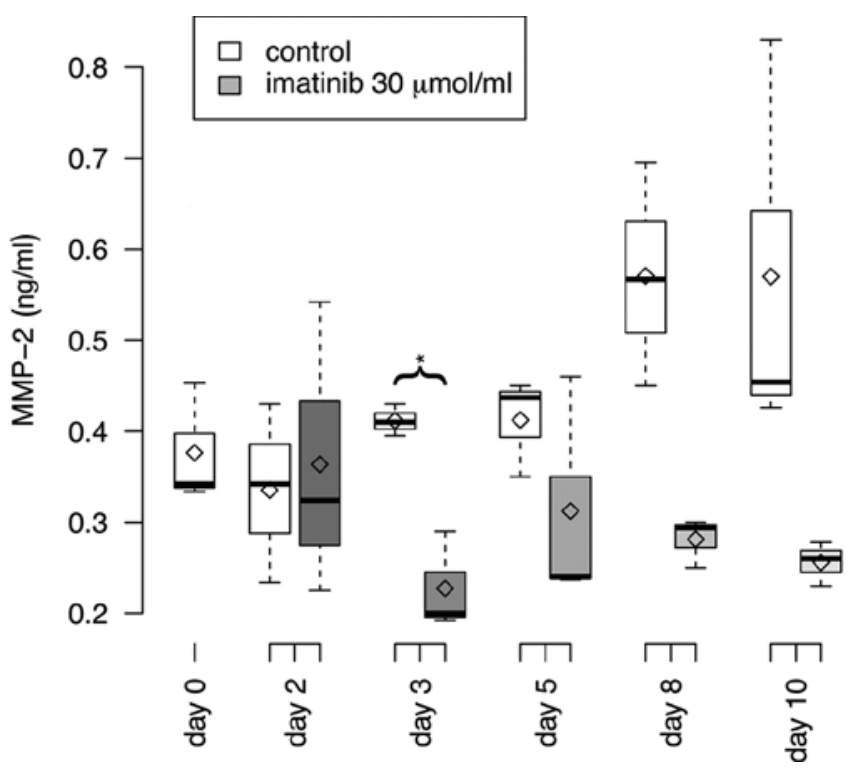

Figure 3. Downregulation of MMP-2 by imatinib in the p16-positive cell line CERV196. The downregulating effect of imatinib could only be measured significantly on day 3 in p16 positive CERV196 ( $\mathrm{P}=0.007$; $\left.{ }^{*} \mathrm{P}<0.05\right)$.

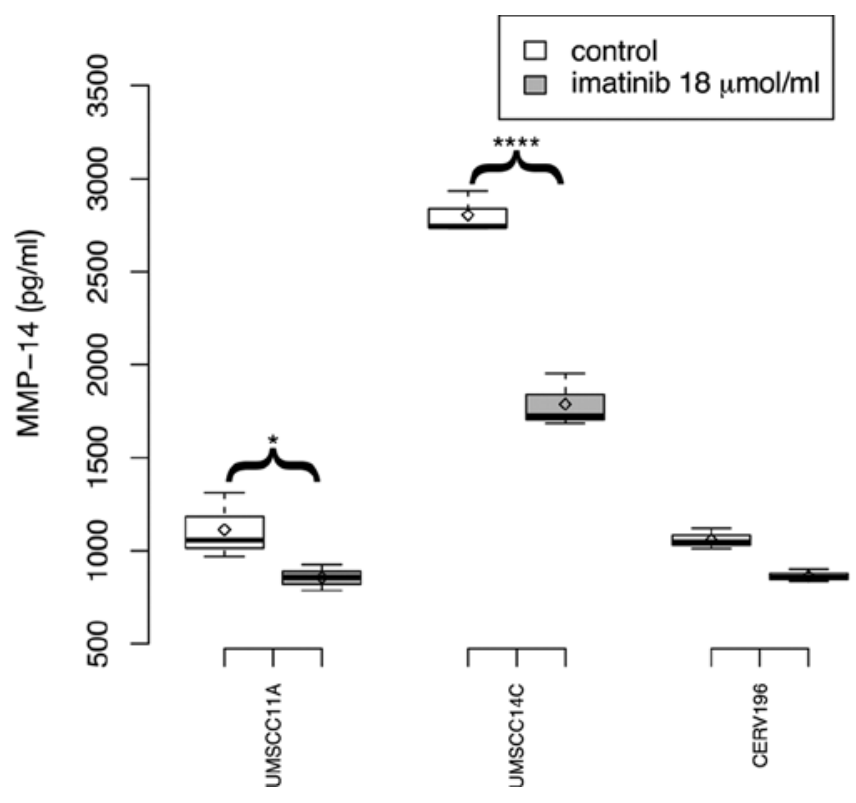

Figure 4. Downregulation of MMP-14 by imatinib in SCC. Significant suppression of MMP-14 expression could be measured in all cell lines treated with imatinib. However, the effect on CERV196 was less striking than in HNSCC cell lines 11A and 14C. A significant downregulation of MMP-14 could be measured in HNSCC 11A already after 3 days and in $14 \mathrm{C}$ from day 3 to 10 This could only be observed after 8 days in CERV196 (e.g., $18 \mu$ mol, day 3): cont $_{11 \mathrm{~A}}=1112.77 \pm 177.06 \mathrm{pg} / \mathrm{ml}, \mathrm{m}_{11 \mathrm{~A}}=855.87 \pm 69.80 \mathrm{pg} / \mathrm{ml}, \mathrm{P}_{11 \mathrm{~A}}=0.019(" \mathrm{P}<0.05)$; cont $_{14 \mathrm{C}}=2803.8 \pm 113.24 \mathrm{pg} / \mathrm{ml}, \mathrm{m}_{14 \mathrm{C}}=1788 \pm 144.88 \mathrm{pg} / \mathrm{ml}, \mathrm{P}_{14 \mathrm{C}},<0.0001$ $\left({ }^{* * * * *} \mathrm{P} \leq 0.0006\right) ;$ cont $_{\text {CERV } 196}=1060 \pm 54.99 \mathrm{pg} / \mathrm{ml}, \mathrm{m}_{\text {CERV } 196}=864.48 \pm 34.08 \mathrm{pg} / \mathrm{ml}$.

Strikingly, the downregulating effect of imatinib could only be measured significantly on day 3 in p16 positive CERV196 $(\mathrm{P}=0.007)$. The effect of imatinib seemed to be weaker in CERV196 (Fig. 3).

In HNSCC cell lines 11A and 14C, we observed a 2-fold higher expression of MMP-2 compared to p16-positive

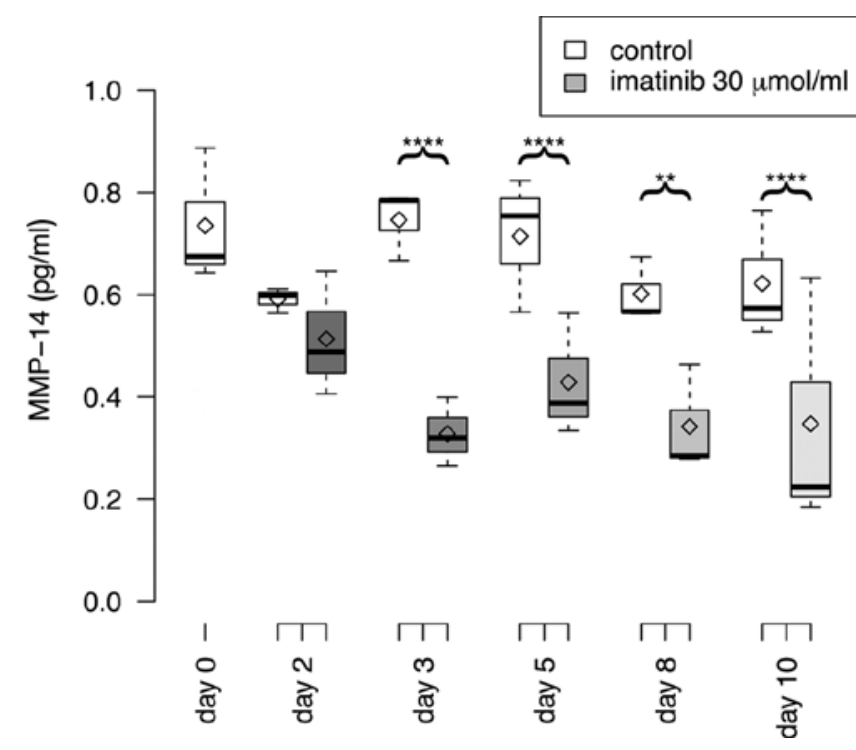

Figure 5. Downregulation of MMP-14 by imatinib in HNSCC 14C. Especially in HNSCC $14 \mathrm{C}$ a highly significant effect of imatinib on MMP-14 expression was revealed and observed from day 3 to 10 (e.g., $30 \mu \mathrm{mol}):$ cont $_{0 \mathrm{~d}}=1509.93 \pm 145.39 \mathrm{pg} / \mathrm{ml}$, cont $_{2 \mathrm{~d}}=1989.1 \pm 253.33 \mathrm{pg} / \mathrm{ml}$, $\mathrm{m}_{2 \mathrm{~d}}=1887 \pm 176.44 \mathrm{pg} / \mathrm{ml}$, cont $_{3 \mathrm{~d}}=2803.8 \pm 113.24 \mathrm{pg} / \mathrm{ml}, \mathrm{m}_{3 \mathrm{~d}}=1696 \pm 226.81 \mathrm{pg} /$ $\mathrm{ml}, \mathrm{P}_{3 \mathrm{~d}}<0.0001 \quad\left({ }^{* * * *} \mathrm{P} \leq 0.0006\right) ;$ cont $_{5 \mathrm{~d}}=2677.67 \pm 99.73 \mathrm{pg} / \mathrm{ml}$, $\mathrm{m}_{5 \mathrm{~d}}=1538 \pm 95.36 \mathrm{ng} / \mathrm{ml}, \mathrm{P}_{5} \mathrm{~d}<0.0001\left({ }^{* * * * *} \mathrm{P} \leq 0.0006\right) ;$ cont $_{8 \mathrm{~d}}=2181 \pm 695.05 \mathrm{pg} / \mathrm{ml}$, $\mathrm{m}_{8 \mathrm{~d}}=1073.67 \pm 208.36 \mathrm{pg} / \mathrm{ml}, \mathrm{P}_{8 \mathrm{~d}}=0.0022\left({ }^{* * *} \mathrm{P}<0.005\right) ;$ cont $_{10 \mathrm{~d}}=1775.67 \pm 188.17 \mathrm{pg} /$ $\mathrm{ml}, \mathrm{m}_{10 \mathrm{~d}}=980 \pm 229.79 \mathrm{pg} / \mathrm{ml}, \mathrm{P}_{10 \mathrm{~d}}=0.0001\left({ }^{* * * *} \mathrm{P} \leq 0.0006\right)$.

CERV196 (e.g., negative controle, $0 \mathrm{~d}: \mathrm{m}_{11 \mathrm{~A}}=0.516 \pm 0.098 \mathrm{ng} / \mathrm{ml}$; $\left.\mathrm{m}_{14 \mathrm{C}}=0.735 \pm 0.133 \mathrm{ng} / \mathrm{ml} ; \mathrm{m}_{\text {CERV } 196}=0.376 \pm 0.067 \mathrm{ng} / \mathrm{ml}\right)$.

The significant suppression of MMP-14 expression could be measured in all cell lines treated with imatinib. However, the effect on CERV196 was less striking than in HNSCC cell lines 11A and 14C. A significant downregulation of MMP-14 could be measured in HNSCC 11A already after 3 days and in $14 \mathrm{C}$ from day 3 to 10 . This could only be observed after 8 days in CERV196 (e.g., $18 \mu \mathrm{mol}, 3 \mathrm{~d}$ ): cont $_{11 \mathrm{~A}}=1112.77 \pm 177.06 \mathrm{pg} / \mathrm{ml}, \mathrm{m}_{11 \mathrm{~A}}=855.87 \pm 69.80 \mathrm{pg} / \mathrm{ml}$, $\mathrm{P}_{11 \mathrm{~A}}=0.019 ;$ cont $_{14 \mathrm{C}}=2803.8 \pm 113.24 \mathrm{pg} / \mathrm{ml} \mathrm{m}_{14 \mathrm{C}}=1788 \pm 144.88 \mathrm{pg} /$ $\mathrm{ml}, \mathrm{P}_{14 \mathrm{C}}<0.0001 ;$ cont $_{\mathrm{CERV} 196}=1060 \pm 54.99 \mathrm{pg} / \mathrm{ml}, \mathrm{m}_{\mathrm{CERV} 196}=$ $864.48 \pm 34.08 \mathrm{pg} / \mathrm{ml}$ (Fig. 4).

In UMSCC $14 \mathrm{C}$ a downregulation of MMP-14 was also observed after treatment with carboplatin (e.g., $3 \mu \mathrm{mol}, 3 \mathrm{~d}$ ): cont $_{14 \mathrm{C}}=2803.8 \pm 113.24 \mathrm{pg} / \mathrm{ml}, \mathrm{m}_{14 \mathrm{C}}=2073.33 \pm 115.17 \mathrm{pg} / \mathrm{ml}$, $\mathrm{P}=0.003$.

Especially in HNSCC $14 \mathrm{C}$ a highly significant effect of imatinib on MMP-14 expression was revealed and it could be observed from day 3 to 10 (e.g., $30 \mu \mathrm{mol}$ ): cont $_{0 \mathrm{~d}}=$ $1509.93 \pm 145.39 \mathrm{pg} / \mathrm{ml} ;$ cont $_{2 \mathrm{~d}}=1989.1 \pm 253.33 \mathrm{pg} / \mathrm{ml} ; \mathrm{m}_{2 \mathrm{~d}}=$ $1887 \pm 176.44 \mathrm{pg} / \mathrm{ml} ;$ cont $_{3 \mathrm{~d}}=2803.8 \pm 113.24 \mathrm{pg} / \mathrm{ml}, \mathrm{m}_{3 \mathrm{~d}}=$ $1696 \pm 226.81 \mathrm{pg} / \mathrm{ml}, \mathrm{P}_{3 \mathrm{~d}}<0.0001 ;$ cont $_{5 \mathrm{~d}}=2677.67 \pm 99.73 \mathrm{pg} / \mathrm{ml}$, $\mathrm{m}_{5 \mathrm{~d}}=1538 \pm 95.36 \mathrm{ng} / \mathrm{ml}, \mathrm{P}_{5 \mathrm{~d}}<0.0001 ;$ cont $_{8 \mathrm{~d}}=2181 \pm 695.05 \mathrm{pg} / \mathrm{ml}$, $\mathrm{m}_{8 \mathrm{~d}}=1073.67 \pm 208.36 \mathrm{pg} / \mathrm{ml}, \mathrm{P}_{8 \mathrm{~d}}=0.0022 ;$ cont $_{10 \mathrm{~d}}=$ $1775.67 \pm 188.17 \mathrm{pg} / \mathrm{ml}, \mathrm{m}_{10 \mathrm{~d}}=980 \pm 229.79 \mathrm{pg} / \mathrm{ml}, \mathrm{P}_{10 \mathrm{~d}}=0.0001$ (Fig. 5).

Immunohistochemistry. The immunohistochemical studies against MMP-14 showed decreased reactivity with rising 


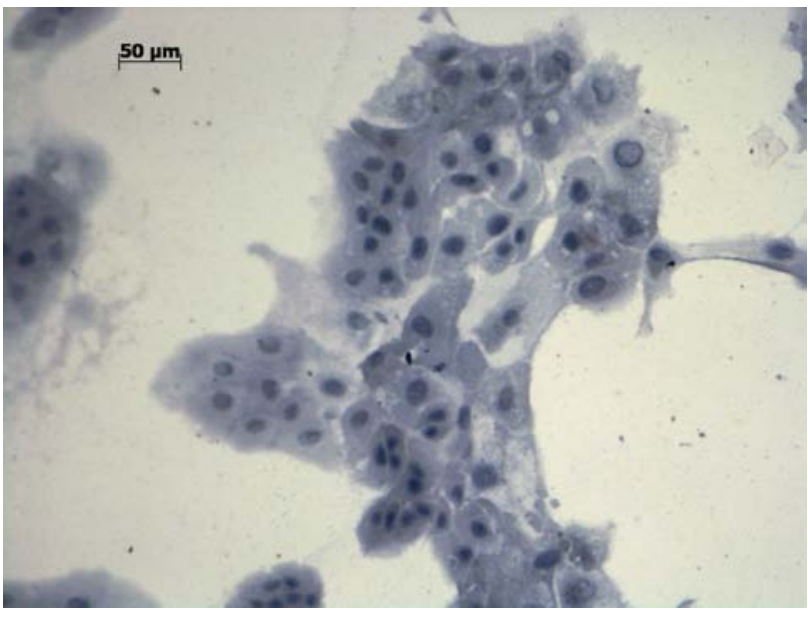

Figure 6. Immunoreactivity against MMP-14 in CERV196.

concentrations of imatinib and with rising time of incubation from 48-240 $\mathrm{h}$ in HNSCC lines 11A and 14C. This effect of imatinib could not be shown for the p16-positive cell line CERV196 (Fig. 6). The effect of carboplatin on MMP expression in HNSCC lines was less striking compared to imatinib (Table I).

\section{Discussion}

The combination of chemo- and radiotherapy of advanced HNSCC was developed to improve the often poor prognosis in these malignancies. Concomitant chemoradiotherapy with cytotoxic chemotherapeutics has improved overall and 5-year survival rates of advanced HNSCC patients and also improved locoregional control rate. But new strategies and targeted therapy have been explored in the attempt to enhance survival rates in advanced HNSCC and especially unresectable HNSCC (33). Countless epigenetic and genetic events, including the aberrant expression and function of regulators of cell cycle, growth and signaling, motility, angiogenesis and apoptosis are involved in pathogenesis of HNSCC and thus might be plausible targets for therapy. Thus, recently intracellular signal transduction has come to special interest also in squamous cell carcinoma. Transmembrane protein tyrosine kinases (PTK) are fundamental elements of the signal transduction. In consequence, they might also be promising targets for cancer therapy. Imatinib (STI 571) was originally designed to inhibit the BCR-ABL tyrosine kinase in chronic myeloid leukaemia (34). In former studies imatinib also showed inhibitory impact on the PTK receptor c-kit and on its PTK activity $(33,35)$. Thus, imatinib has antitumor activities towards adenocarcinoma, e.g., colon cancer, and its antitumoral effects have also been shown in non-small cell lung cancer and HNSCC $(36,37)$. In concequence, we set up the above study to analyze its potency in HNSCC cell lines to confirm these effects. The concentrations of imatinib used in our experiments were within the range that is achieved in a clinical trial (37). Similarly, the concentrations of carboplatin used in this study are clinically relevant. As current phase II clinical trials in aerodigestive tumors were undertaken to evaluate the efficacy of imatinib mesylatedocetaxel, which hypothesized that imatinib mesylate would inhibit platelet-derived growth factor receptor (PDGFR) on pericytes and increase docetaxel uptake, showed partial poor outcome in HNSCC patients (37) we find it very important to put emphasis on cell culture experiments. Imatinib can be administered orally to the patients and comparatively limited

Table I. Immunoreactivity against MMP-14 in HNSCC 11A, 14C and CERV196.

\begin{tabular}{|c|c|c|c|c|}
\hline Immunostaining index & $48 \mathrm{~h}$ & $72 \mathrm{~h}$ & $120 \mathrm{~h}$ & $240 \mathrm{~h}$ \\
\hline \multirow[t]{3}{*}{ Control group } & HNSCC 11A +++ (3/3) & HNSCC $11 \mathrm{~A}+++(2 / 3)$ & HNSCC $11 \mathrm{~A}++(2 / 3)$ & HNSCC $11 \mathrm{~A}+++(3 / 3)$ \\
\hline & HNSCC $14 \mathrm{C}+++(3 / 3)$ & HNSCC $14 \mathrm{C}++(2 / 3)$ & HNSCC $14 \mathrm{C}+++(3 / 3)$ & HNSCC $14 \mathrm{C}+++(2 / 3)$ \\
\hline & CERV196 ++ (3/3) & CERV196 ++ (3/3) & CERV196 +++ (3/3) & CERV196 ++ (2/3) \\
\hline \multirow[t]{3}{*}{ Carboplatin $3 \mu \mathrm{mol}$} & HNSCC $11 \mathrm{~A}++(1 / 3)$ & HNSCC $11 \mathrm{~A}++(2 / 3)$ & HNSCC $11 \mathrm{~A}+++(2 / 3)$ & HNSCC $11 \mathrm{~A}++(1 / 3)$ \\
\hline & HNSCC $14 \mathrm{C}++(2 / 3)$ & $\operatorname{HNSCC} 14 \mathrm{C}+++(1 / 3)$ & HNSCC $14 \mathrm{C}++(1 / 3)$ & HNSCC $14 \mathrm{C}+++(2 / 3)$ \\
\hline & CERV196 +++ (2/3) & CERV196 +++ (1/3) & CERV196 +++ (3/3) & CERV196 +++ (2/3) \\
\hline \multirow[t]{3}{*}{ Carboplatin $7.5 \mu \mathrm{mol}$} & HNSCC $11 \mathrm{~A}+++(2 / 3)$ & HNSCC $11 \mathrm{~A}++(2 / 3)$ & HNSCC $11 \mathrm{~A}++(2 / 3)$ & HNSCC $11 \mathrm{~A}++(2 / 3)$ \\
\hline & HNSCC14C ++ (2/3) & HNSCC $14 \mathrm{C}+++(2 / 3)$ & HNSCC $14 \mathrm{C}++(1 / 3)$ & HNSCC $14 \mathrm{C}+++(1 / 3)$ \\
\hline & CERV196 +++(3/3) & CERV196 +++ (3/3) & CERV196 +++ (2/3) & CERV196 +++ (2/3) \\
\hline \multirow[t]{3}{*}{ Imatinib $18 \mu \mathrm{mol}$} & HNSCC $11 \mathrm{~A}++(2 / 3)$ & HNSCC $11 \mathrm{~A}+(2 / 3)$ & HNSCC $11 \mathrm{~A}+(1 / 3)$ & HNSCC $11 \mathrm{~A}+(1 / 3)$ \\
\hline & HNSCC $14 \mathrm{C}++(1 / 3)$ & HNSCC $14 \mathrm{C}++(1 / 3)$ & HNSCC $14 \mathrm{C}++(1 / 3)$ & HNSCC $14 \mathrm{C}++(2 / 3)$ \\
\hline & CERV196 +++ (3/3) & CERV196 & CERV196 ++ (1/3) & CERV196 ++ (2/3) \\
\hline \multirow[t]{3}{*}{ Imatinib $30 \mu \mathrm{mol}$} & HNSCC $11 \mathrm{~A}++(2 / 3)$ & HNSCC 11A $0(1 / 3)$ & HNSCC $11 \mathrm{~A}+(1 / 3)$ & HNSCC 11A $0(1 / 3)$ \\
\hline & HNSCC $14 \mathrm{C}+(2 / 3)$ & HNSCC $14 C+(2 / 3)$ & HNSCC $14 \mathrm{C}++(2 / 3)$ & $\operatorname{HNSCC} 14 \mathrm{C}+(1 / 3)$ \\
\hline & CERV196 ++ (2/3) & CERV196 ++ (1/3) & CERV196 ++ (2/3) & CERV196 + (1/3) \\
\hline
\end{tabular}

0 , no positive cells; + , weak immunostaining; ++ , moderate immunostaining; +++ , strong immunostaining. $(\mathrm{x} / 3)$, number of positive cell lines out of the HNSCC lines 14C, 11A and CERV196. 
toxic side effects have been reported (38). It is possible that the main part of toxicity was contributed by docetaxel in the above mentioned trial.

Furthermore, the role of MMPs in tumor progress, invasion and metastasis has already been extensively studied $(33,39,40)$. Hereby MMPs are responsible for the alteration of basement membrane collagens (41). In our experiments we illustrated a remarkable expression of MMP-2 and -14 in all cell lines tested (HNSCC 11A, 14C and CERV196). The expression of MMPs was significantly reduced after incubation with imatinib in different concentrations in HNSCC cell lines. This effect could also be observed in p16-positive CERV196, even though the effect was moderate compared to HNSCC lines 11A and 14C. Epidemiological and experimental studies have provided evidence that human papillomavirus (HPV) infection plays an important role in the development of e.g., uterine cervical neoplasms (42) or neoplasms of the head and neck (43). In the past emphasis has been put on two of the enzymes, MMP-2 and MMP-9 which have been correlated with the progress of tumor cell invasion and metastasis in human cancers, including uterine neoplasms (42). They are potent gelatinases and have been correlated with the processes of tumor cell invasion and metastasis (42). MMP-2 (gelatinase A) (44) and MMP-9 (gelatinase B) have been found in large quantities in cancer tissues $(41,45)$. Overexpression of MMP-2 and -9 has been observed in pre-cancer and cancer lesions of the cervical uterine (42). During the last decades progress in research on enzyme activities showed the potential significance of MMP-2 and MMP-9 in the progress of cervical uterine cancer suggesting their prognostic value $(42,46,47)$. MMP-2 expression was suppressed in the presence of imatinib in our cell cultures. MMP-2 seems to play a key role in degradation of basement membranes, which facilitates invasion and metastasis of tumor cells. The overexpression of MMP-2 is associated with local invasion of the tumor, lymph node metastasis and a poor survival rate (48). Fibroblasts secrete several growth factors, such as SCF, HGF, IGF and TGF- $\beta(49,50)$. A proteolytic cleavage by MMPs might activate these growth factors, which leads to HNSCC cell growth. TGF- $\beta$ and IGF are factors known to increase the membrane MMP-2 expression in smooth muscle (51). HGF might enhance the invasiveness of HNSCC by the induction of Ets-related E1AF transcription factor genes, whose products again activate MMP genes (52). Furthermore, HGF may foster the tumor invasion progress by inducing a loss of $\beta$-catenin/ cadherin-mediated cell-cell adhesion (53). Recent studies revealed an alteration of these cell-cell adhesion proteins in HNSCC by suindac sulfone (54). Thus, a model summarizing the interactions between HNSCC cells and stromal fibroblasts may contain the secretion of growth factors by fibroblasts that foster the expression of MMPs.

MMP-14, a membrane-type-MMP, is a critical protein in cancer invasion and metastasis (31). Invasion through collagen networks and subsequent collagenolysis relies principally on MMP-14, not on secreted MMPs (32). It has now been shown, that MMP-14 interacts with CD44, a membrane-associated glycoprotein, which has also been shown to be a cancer stem cell marker in HNSCC $(31,55,56)$. By this interaction a migratory front is created, which enables the cells to migrate through the tissue in the direction led by MMP-14 (31). To minimize the remodeling of extracellular matrix necessary for tissue invasion, MMP-14 is localized at the leading edge of the cell, the invadopodia $(31,57)$.

In conclusion, we have shown that HNSCC cell lines and the p16-positive cell line CERV196 express MMP-2 and -14. We demonstrated that imatinib alone and as a combination with carboplatin can be very effective in downregulation of MMP-expression especially in HNSCC. Therefore, imatinib may exert in part its inhibitory effect on tumor cell growth via the blockage of the signal transduction of PTK receptor (33). Because of the low toxicity of imatinib alone in humans, further studies should be considered to further explore its potency in antitumoral therapy in HNSCC.

\section{Acknowledgements}

The authors would like to thank Petra Prohaska for excellent technical assistance, Dr C. Weiss for her assistance in statistical analysis, and Novartis Pharma (Basel, Switzerland) for kindly providing imatinib.

\section{References}

1. Edwards BK, Howe HL, Ries LA, et al: Annual report to the nation on the status of cancer, 1973-1999, featuring implications of age and aging on U.S. cancer burden. Cancer 94: 2766-2792, 2002 .

2. Vokes EE, Weichselbaum RR, Lippman SM and Hong WK: Head and neck cancer. N Engl J Med 328: 184-194, 1993.

3. Dimery IW and Hong WK: Overview of combined modality therapies for head and neck cancer. J Natl Cancer Inst 85: 95-111, 1993.

4. Gallo O, Chiarelli I, Boddi V, Bocciolini C, Bruschini L and Porfirio B: Cumulative prognostic value of p53 mutations and bcl-2 protein expression in head-and-neck cancer treated by radiotherapy. Int J Cancer 84: 573-579, 1999.

5. Grandis JR, Chakraborty A, Zeng Q, Melhem MF and Tweardy DJ: Downmodulation of TGF- $\alpha$ protein expression with antisense oligonucleotides inhibits proliferation of head and neck squamous carcinoma but not normal mucosal epithelial cells. J Cell Biochem 69: 55-62, 1998.

6. Pignataro L, Pruneri G, Carboni N, et al: Clinical relevance of cyclin D1 protein overexpression in laryngeal squamous cell carcinoma. J Clin Oncol 16: 3069-3077, 1998.

7. Riechelmann H, Sauter A, Golze W, et al: Phase I trial with the CD44v6-targeting immunoconjugate bivatuzumab mertansine in head and neck squamous cell carcinoma. Oral Oncol 44: 823-829, 2008

8. Sauter A, Kloft C, Gronau S, et al: Pharmacokinetics, immunogenicity and safety of bivatuzumab mertansine, a novel CD44v6-targeting immunoconjugate, in patients with squamous cell carcinoma of the head and neck. Int J Oncol 30: 927-935, 2007.

9. Rijkaart DC, Berkhof J, Rozendaal L, et al: Human papillomavirus testing for the detection of high-grade cervical intraepithelial neoplasia and cancer: final results of the POBASCAM randomised controlled trial. Lancet Oncol 13: 78-88, 2012.

10. Mendoza N, Hernandez PO and Tyring SK: HPV vaccine update: new indications and controversies. Skin Therapy Lett 16: 1-3, 2011.

11. Antonsson A, Spurr TP, Chen AC, et al: High prevalence of human papillomaviruses in fresh frozen breast cancer samples. J Med Virol 83: 2157-2163, 2011.

12. Shiboski CH, Schmidt BL and Jordan RC: Tongue and tonsil carcinoma: increasing trends in the U.S. population ages 20-44 years. Cancer 103: 1843-1849, 2005.

13. Gillison ML, Koch WM, Capone RB, et al: Evidence for a causal association between human papillomavirus and a subset of head and neck cancers. J Natl Cancer Inst 92: 709-720. 2000.

14. Nasman A, Attner P, Hammarstedt L, et al: Incidence of human papillomavirus (HPV) positive tonsillar carcinoma in Stockholm, Sweden: an epidemic of viral-induced carcinoma? Int J Cancer 125: 362-366, 2009. 
15. Attner P, Du J, Nasman A, et al: The role of human papillomavirus in the increased incidence of base of tongue cancer. Int $\mathrm{J}$ Cancer 126: 2879-2884, 2010.

16. Romanitan M, Nasman A, Ramqvist T, et al: Human papillomavirus frequency in oral and oropharyngeal cancer in Greece. Anticancer Res 28: 2077-2080, 2008.

17. Chaturvedi AK, Engels EA,Pfeiffer RM, et al: Human papillomavirus and rising oropharyngeal cancer incidence in the United States. J Clin Oncol 29: 4294-4301, 2011.

18. Kreimer AR, Clifford GM, Boyle P and Franceschi S: Human papillomavirus types in head and neck squamous cell carcinomas worldwide: a systematic review. Cancer Epidemiol Biomarkers Prev 14: 467-475, 2005.

19. Kreimer AR and Chaturvedi AK: HPV-associated oropharyngeal cancers - are they preventable? Cancer Prev Res 4: 1346-1349, 2011.

20. Koch WM, Lango M, Sewell D, Zahurak M and Sidransky D: Head and neck cancer in non-smokers: a distinct clinical and molecular entity. Laryngoscope 109: 1544-1551, 1999.

21. Crosby RA, Diclemente RJ, Salazar LF, Nash R, Younge S and Head S: Human papillomavirus vaccine intention among college men: what's oral sex got to do with it? J Am Coll Health 60: 8-12, 2012.

22. Rautava J, Kuuskoski J, Syrjanen K, Grenman R and Syrjanen S HPV genotypes and their prognostic significance in head and neck squamous cell carcinomas. J Clin Virol 53: 116-120, 2012.

23. Blume-Jensen $P$ and Hunter T: Oncogenic kinase signalling. Nature 411: 355-365, 2001.

24. Ford AC and Grandis JR: Targeting epidermal growth factor receptor in head and neck cancer. Head Neck 25: 67-73, 2003.

25. Lydon NB and Druker BJ: Lessons learned from the development of imatinib. Leuk Res 28 (Suppl 1): S29-S38, 2004.

26. Buchdunger E, Zimmermann J, Mett H, et al: Inhibition of the $\mathrm{Abl}$ protein-tyrosine kinase in vitro and in vivo by a 2-phenylaminopyrimidine derivative. Cancer Res 56: 100-104, 1996.

27. Druker BJ, Tamura S, Buchdunger E, et al: Effects of a selective inhibitor of the Abl tyrosine kinase on the growth of Bcr-Abl positive cells. Nat Med 2: 561-566, 1996.

28. Bran B, Bran G, Hormann K and Riedel F: The platelet-derived growth factor receptor as a target for vascular endothelial growth factor-mediated anti-angiogenetic therapy in head and neck cancer. Int J Oncol 34: 255-261, 2009.

29. O-Charoenrat P, Rhys-Evans PH and Eccles SA: Expression of matrix metalloproteinases and their inhibitors correlates with invasion and metastasis in squamous cell carcinoma of the head and neck. Arch Otolaryngol Head Neck Surg 127: 813-820, 2001

30. Okada A, Bellocq JP, Rouyer N, et al: Membrane-type matrix metalloproteinase (MT-MMP) gene is expressed in stromal cells of human colon, breast, and head and neck carcinomas. Proc Nat Acad Sci USA 92: 2730-2734, 1995.

31. Zarrabi K, Dufour A, Li J, et al: Inhibition of matrix metalloproteinase-14 (MMP-14)-mediated cancer cell migration. J Biol Chem 286: 33167-33177, 2011.

32. Sabeh F, Li XY, Saunders TL, Rowe RG and Weiss SJ: Secreted versus membrane-anchored collagenases: relative roles in fibroblast-dependent collagenolysis and invasion. J Biol Chem 284: 23001-23011, 2009.

33. Schultz JD, Rotunno S, Erben P, et al: Down-regulation of MMP-2 expression due to inhibition of receptor tyrosine kinases by imatinib and carboplatin in HNSCC. Oncol Rep 25: 1145-1151, 2011.

34. Druker BJ and Lydon NB: Lessons learned from the development of an abl tyrosine kinase inhibitor for chronic myelogenous leukemia. J Clin Invest 105: 3-7, 2000.

35. Heinrich MC, Griffith DJ, Druker BJ, Wait CL, Ott KA and Zigler AJ: Inhibition of c-kit receptor tyrosine kinase activity by STI 571, a selective tyrosine kinase inhibitor. Blood 96: 925-932, 2000.

36. Popow-Wozniak A, Wozniakowska A, Kaczmarek L, MalickaBlaszkiewicz M and Nowak D: Apoptotic effect of imatinib on human colon adenocarcinoma cells: influence on actin cytoskeleton organization and cell migration. Eur J Pharmacol 667: 66-73, 2011.
37. Tsao AS, Liu S, Fujimoto J, et al: Phase II trials of imatinib mesylate and docetaxel in patients with metastatic non-small cell lung cancer and head and neck squamous cell carcinoma. J Thorac Oncol 6: 2104-2111, 2011.

38. Hirota S, Isozaki K, Moriyama Y, et al: Gain-of-function mutations of c-kit in human gastrointestinal stromal tumors. Science 279: 577-580, 1998.

39. Gorogh T, Beier UH, Baumken J, et al: Metalloproteinases and their inhibitors: influence on tumor invasiveness and metastasis formation in head and neck squamous cell carcinomas. Head Neck 28: 31-39, 2006.

40. Moscatelli D and Rifkin DB: Membrane and matrix localization of proteinases: a common theme in tumor cell invasion and angiogenesis. Biochim Biophys Acta 948: 67-85, 1988.

41. Liotta LA and Stetler-Stevenson WG: Tumor invasion and metastasis: an imbalance of positive and negative regulation. Cancer Res 51: S5054-S5059, 1991.

42. Libra M, Scalisi A, Vella N, et al: Uterine cervical carcinoma: role of matrix metalloproteinases (review). Int J Oncol 34: 897-903, 2009.

43. Gondivkar SM, Parikh RV, Gadbail AR, et al: Involvement of viral factors with head and neck cancers. Oral Oncol: Nov 9, 2011 (Epub ahead of print).

44. Fernandes T, de Angelo-Andrade LA, Morais SS, et al: Stromal cells play a role in cervical cancer progression mediated by MMP-2 protein. Eur J Gynaecol Oncol 29: 341-344, 2008.

45. Giannelli G, Falk-Marzillier J, Schiraldi O, Stetler-Stevenson WG and Quaranta V: Induction of cell migration by matrix metalloprotease-2 cleavage of laminin-5. Science 277: 225-228, 1997.

46. Sheu BC, Lien HC, Ho HN, et al: Increased expression and activation of gelatinolytic matrix metalloproteinases is associated with the progression and recurrence of human cervical cancer. Cancer Res 63: 6537-6542, 2003.

47. Yang SF, Wang PH, Lin LY, et al: A significant elevation of plasma level of matrix metalloproteinase-9 in patients with high-grade intraepithelial neoplasia and early squamous cell carcinoma of the uterine cervix. Reprod Sci 14: 710-718, 2007.

48. Seiki M: Membrane-type 1 matrix metalloproteinase: a key enzyme for tumor invasion. Cancer Lett 194: 1-11, 2003.

49. Mook OR, Frederiks WM and van Noorden CJ: The role of gelatinases in colorectal cancer progression and metastasis. Biochim Biophys Acta 1705: 69-89, 2004.

50. Shimizu M, Minakuchi K, Tsuda A, et al: Role of stem cell factor and c-kit signaling in regulation of fetal intestinal epithelial cell adhesion to fibronectin. Exp Cell Res 266: 311-322, 2001.

51. Risinger GM Jr, Hunt TS, Updike DL, Bullen EC and Howard EW: Matrix metalloproteinase-2 expression by vascular smooth muscle cells is mediated by both stimulatory and inhibitory signals in response to growth factors. J Biol Chem 281: 25915-25925, 2006.

52. Hanzawa M, Shindoh M, Higashino F, et al: Hepatocyte growth factor upregulates E1AF that induces oral squamous cell carcinoma cell invasion by activating matrix metalloproteinase genes. Carcinogenesis 21: 1079-1085, 2000.

53. Hiscox S and Jiang WG: Hepatocyte growth factor/scatter factor disrupts epithelial tumour cell-cell adhesion: involvement of beta-catenin. Anticancer Res 19: 509-517, 1999.

54. Sauter A, Soulsby H, Hormann K and Naim R: Sulindac sulfone induces a decrease of $\beta$-catenin in HNSCC. Anticancer Res 30: 339-343, 2010.

55. Faber A, Barth C, Hormann K, et al: CD44 as a stem cell marker in head and neck squamous cell carcinoma. Oncol Rep 26: 321-326, 2011.

56. Mori H, Tomari T, Koshikawa N, et al: CD44 directs membranetype 1 matrix metalloproteinase to lamellipodia by associating with its hemopexin-like domain. EMBO J 21: 3949-3959, 2002.

57. Artym VV, Zhang Y, Seillier-Moiseiwitsch F, Yamada KM and Mueller SC: Dynamic interactions of cortactin and membrane type 1 matrix metalloproteinase at invadopodia: defining the stages of invadopodia formation and function. Cancer Res 66 : 3034-3043, 2006. 